\title{
Peace as the purpose of the military
}

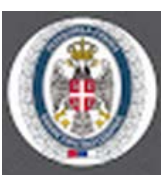

Received: $19 / 09 / 2021$

Revised: 01/10/2021

Accepted: 08/10/2021

Published: 06/12/2021

Corresponding author:

Dragan Stanar

Correspondence email:

draganstanar@unionnikolatesla.edu.rs

DOI: $10.5937 /$ vojdelo2103036S

\begin{tabular}{|l|l|l|l|}
\hline c & e & o & n \\
\hline c & e & e & s \\
\hline
\end{tabular}

\author{
Dragan Stanar \\ Univerzitet Union - Nikola Tesla, Fakultet za međunarodnu politiku i \\ bezbednost, Beograd
}

\begin{abstract}
:
The attitude of political system, and in a broader sense of political community, towards the military is largely defined by the understanding of the role and purpose that the military has in a society. The lack of the understanding of the true purpose of the military often leads to inadequate evaluation of this institution, both in political system and by general public. The objective of this paper is to define peace as the purpose of the military, which will enable a proper understanding of its vital political role as a necessary framework and preconditions for the existence and functioning of all other institutions in the society. The paper analyzes the perception of the role of the military institution and its members and offers an alternative definition of its function and purpose, which facilitates correct insight into the role of the military in the society and depicts its essential nature. An intuitive understanding of the role of the military, through misinterpretation of instrument (war) as the purpose itself, reduces its purpose to war, and thus determines the attitude of the lay political public towards this institution and its members. Therefore, it is necessary to offer an adequate answer to the question: why the purpose of the military is actually peace and not war, what kind of peace it is, and by which functions this institution fulfills its role. It is concluded that the military exercises the defined purpose of "good" peace in two ways - in peace by preserving it through the function of deterrence, and in war by establishing it as quickly as possible through victory.
\end{abstract}

Keywords: the military; peace; war; purpose; means; laws

\section{INTRODUCTION}

One of the common denominators of the meaning of the attributes postmodern, posthistoric, neoliberal, etc., which often describe and define the modern age, is certainly the revaluation and reexamination of the main values of human societies, which for centuries and perhaps millennia have been the spiritual foundation of stability and the existence of every human community. However, the modern age and modern human societies bring not only re-examination of values, but also almost all other phenomena including vital social mechanisms, processes and institutions. Rethinking the meaning, function, role and general meaning of some institutions in modern societies, even those of vital and essential importance, such as the armed forces, very often acquires the proportions of unlimited criticism and challenge, especially in view of the communication revolution of new media that enable strong social and political pressure ${ }^{2}$. Such uncritical re-examination and revaluation of the significance and general existence of institutions such as the armed forces conditions their position in the society, i.e. the relationship of political system and the entire political community ${ }^{3}$, and also the society towards them, the relationship that largely determines the status of these institutions within the society.

If, for the purposes of this paper, we ignore the obvious and unequivocally clear forces ${ }^{4}$ that latently stand behind such processes of revaluation and re-examination of key social institutions, we will face the unpleasant fact that often the misunderstanding of the meaning, function and purpose of a particular institution is at the root of its unfavourable status and position within the society and political system and the inadequate attitude of political elites that make key political decisions. The institution 
of the military, i.e the armed forces of a country, often takes a position in the society and within political system that inadequately reflects its essential significance and importance for the optimal functioning of not only all other elements and institutions of political system, but the society as a whole. One of the reasons for this phenomenon is the mentioned misunderstanding of its purpose. Therefore, a correct and complete understanding of the role and purpose of the armed forces is a necessary precondition for objective and proper evaluation of this institution, an adequate attitude of political system towards the military and the appropriate status and reputation of the armed forces members in the society.

\section{THE MILITARY AND WAR}

Although the concept of the military or armed forces is usually defined as "the subject of the defence of vital state and national values and interests" [1] from threats that are mostly external, it is intuitively primarily understood as semantically inseparable from the concept of war. The concepts of the military and war are certainly not identical or equivalent concepts ${ }^{5}$, but the very phenomenon of war and its essential nature are inseparable from the understanding of the military and its role. Therefore, it is not surprising that these two concepts are often perceived as necessarily and inextricably linked, to the extent that the concept of the military is almost intuitively "reduced" to the concept of war, in terms of understanding the nature, purpose and function of the military. This, somewhat expected, frequent mistake in reducing the overall meaning and function of the military to war has very negative and profound implications for the status and position of the military and its members in the society, and for the relationship of the rest of political system with the military institution, i.e. the armed forces. One of the factors that contributes to such perception of the military is the use of the term "defence", which is unavoidable in the context of the military ${ }^{6}$. As it could be noticed in the very definition of the concept of the military, and also in the discourse of the military and in the concepts used in the context of the military ${ }^{7}$, it is inevitable to perceive the military as an institution serving for the country's defence ${ }^{8}$, implicitly implying the use of the armed force as the defence means ${ }^{9}$. However, one of the specifics of the defence concept is that "it necessarily presupposes the existence of an actual attack by its nature" [2] which, thus, necessarily precedes it. The very word defence in the Serbian language primarily means "a measure of protection from an enemy attack" [3], i.e. a phenomenon that has to be preceded chronologically by an attack. In the context of the armed forces, the armed defence has to be preceded by an attack, while the category of pre-emptive ${ }^{10}$ strike means action that takes place before the enemy attacks - "against an aggressor who intends to attack and whose attack is certain, but has not begun yet" [4]. Unfortunately, "the difference between prevention and pre-emption has become blurred" [5] in the modern world, especially after the terrorist attacks on New York and Washington in 2001.

So, when the military "defends a country from external armed threats" [6], that is, from an attack that necessarily precedes defence, we are talking about a form of political violence that we call war. Although the line between various forms of political violence has become very blurred in the modern world, war can be broadly defined as a complex form of political violence that implies "mass, relatively long-lasting, collective conflict of opposing political communities using primarily armed violence, which is carried out directly and indirectly, and its goal is to impose the will on the opponent, or his complete extermination" [7]. Having that in mind, the common lay intuitive conclusion, which is ultimately incorrect, that the purpose of the military is war, that is, defence against an external armed attack, is not surprising. Such a conclusion, although the result of the shallow and superficial understanding of both the military and war, has interesting implications. If the armed forces are perceived as an institution whose purpose is war, their existence and functioning in time when there are no attacks or indications of attacks, i.e. in times of peace, cannot be properly understood. Unfortunately, this misunderstanding leads to inadequate evaluation of the position of this institution and an inadequate attitude towards it by the rest of political system and general public in the period of peace, because the understanding that the military serves for war, unfortunately, leads to the tendency to conclude that the military does not serve anything when there is no war, or when there is no indication 
that there will be war - defence is by definition impossible when there is no attack, and attack is something that may come sometimes, and may never come. The longer the period of peace is, the more the justification of the existence of an institution, whose purpose is something that is currently lacking, and perhaps is not even in sight, is being questioned. This conclusion is followed by the perception of the military by the public as a burden to the society, as too expensive, redundant, cumbersome and finally unnecessary ${ }^{11}$ institution for which funds are allocated each year, which can be "better" spent on things from which the society has a current benefit ${ }^{12}$. It naturally follows that the status of the armed forces members in the society is, euphemistically speaking, inappropriate. Unfortunately, it is not rare for this misperception of the military to be shared by some parts of political community and political system together with the lay public, which makes the position of the institution of the armed forces and its members even more unfavourable. Therefore, it is necessary to offer theoretical clarification of the nature of the armed forces and to make a distinction between the purpose of the military and the instruments, i.e. the means by which that purpose is fulfilled in an effort to improve the position of the armed forces in the society and political system.

\section{THE MILITARY AND PEACE}

War and peace represent a kind of dialectical pair - not only are these two phenomena in a contrary relationship, but they are also in such a dialectical relationship in which one is necessarily defined by the non-existence of the other ${ }^{13}$. The correct and complete definition of peace is therefore conditioned by the negation of war, that is, as Babić concludes "'peace' is a name for the state of affairs that gains its meaning only in relation to its opposite, namely the state of the absence of peace" [8], i.e. the state of war. Everything that substantially makes peace - stability, predictability, (relative) control of the future and, of course, clearly defined and enforceable laws - is suspended in war in which "rules" and norms that are unthinkable in peace are implemented [9]. Having in mind the essential opposite of the very nature of the phenomenon of war and peace, the dangerous consequence of perceiving war as the purpose of the military would be its "purposelessness", almost redundancy in the state of peace which is, by definition, a state in which there is no war and which does not have points of contact with it. This, of course, does not mean that our assertion is that the phenomenon of war has no place in the context of the military - on the contrary, it is definitely central and primary for the armed forces, but not as purpose, but as a means to an end. The very purpose of the military is peace. The perception of the means or instrument by which the armed forces are used as the very purpose of their existence is obviously grotesquely wrong in this case, since the correct purpose of peace is not replaced by some other (wrong, but similar, close and related purpose), but just the opposite one and incompatible with peace - war. Understanding war as the purpose of the military is as wrong as understanding arrest as the purpose of the police, dissecting a stomach as the purpose of a surgeon, or renunciation as the purpose of Christianity. The purpose, function and meaning of the armed forces is not, therefore, to wage war but to achieve, preserve and protect peace ${ }^{14}$. The means or instrument by which this purpose is fulfilled, is war, among other things.

War is not the only, but it is certainly the primary means of achieving the purpose of peace for the armed forces ${ }^{15}$. The goal of the armed forces in war is to achieve peace through victory, both as quickly and efficiently as possible and with as few casualties as possible on both sides ${ }^{16}$. This once again reflects the true purpose of the military - if war were the purpose of the military, it would certainly be meaningless to strive for its completion as quickly and efficiently as possible, that is, achieving peace. Moreover, as Huntington says in his famous book The Soldier and the State in which he discusses the position of the military in the society, the loudest opposition to war often comes from the military when this option is "on the table", because "a soldier has a tendency to see himself as an eternal victim of civil warmongering" [10]. It really seems that peace sometimes has no greater advocates than those who are part of the armed forces. The peace that is sought and achieved by war, however, is not any kind of peace. From Aristotle and Aurelius Augustine through Kant to the present day, there has been a constant thread of the idea of lasting and sustainable peace as the goal of war. Certainly the peace that seeks to be achieved by war has to be better than the one that existed, because it is 
obvious that the state of ante bellum was unsustainable and that it generated casus belli. Thus, it is often necessary to emphasize that peace has to always contain the option and possibility of war, because without that option there is no key value of freedom in peace ${ }^{17}$. Although the phenomenon of peace really has "a prima facie positive, and war a negative value" [8], it is absolutely possible, and unfortunately often happens, that peace becomes an unbearable and highly undesirable state that needs to be changed. This change is sometimes necessarily achieved by war, for which, of course, the military is used, and which should bring acceptable and sustainable peace ${ }^{18}$. A broader definition of the purpose of the armed forces could certainly include the attributes: lasting, sustainable, favourable, good or at least acceptable peace, using the means of war to gain benefit.

Although war, as explained, is the primary means of achieving the purpose and function of the military, it is certainly not its only instrument. In addition to achieving better and more stable peace through war, the function of the armed forces is also to preserve and protect the existing peace, if such a state enables acceptable life for the society. Unlike war, which is by its nature a temporary state that is conceived as a period that needs to pass, peace is "normatively conceived as a permanent state of affairs" [8], a state that is "normal" and that should last. However, it should not be forgotten that the conception of peace as a permanent state entails the processes of production, maintenance and protection of such a state, in which, in essence, war is successfully avoided. The military institution has a vital role in maintaining and protecting peace. That is, with its existence and efficiency, it directly enables the avoidance of war, fulfilling the function of deterring potential attacks. Since war was a necessary means of creating acceptable peace, deterrence is a necessary means of its protection and preservation. is There is no peace that is not protected or guaranteed by an armed force anywhere on the planet, just as there is no piece of inhabited territory that is not under the protection of some military ${ }^{19}$. In both cases, the armed forces fulfill their purpose - to create and maintain acceptable peace, relying on two different means - war and deterrence. The difference is that in the period of creating acceptable peace, i.e. in war (in transition from unacceptable to acceptable peace), the function of the military is seen unequivocally and evidently, while in the period of protection and preservation of acceptable peace, i.e. when there is no war, it is somehow neglected, underestimated and (un)intentionally "forgotten". Such "forgetting" and underestimation of the essential function and role of the armed forces in peace is particularly dangerous when it "spills over" from the wider lay public to the political system institutions, i.e. political decision-makers who create relations between political system and the military and influence the status of the institution and its members in the society.

\section{PEACE WITHOUT THE MILITARY?}

By its nature, war is obviously impossible in the modern world without the armed forces, although the military is not the only entity that takes part in it. However, an even more important and interesting question is whether good and acceptable peace is possible for a state without the military. The relevance of this issue is specially strengthened by the aforementioned relativization of the importance of the military in the society and political system and the (un)intentional encouragement of the perception of the armed forces as a kind of burden to the rest of the society. From the previous discussion on the differentiation between the purpose and means of the armed forces, it can be clearly concluded that the achievement and preservation of acceptable peace is impossible today without (some) military ${ }^{20}$. The position and status of the military and its members in the society and the relations of political system towards the institution of the armed forces have to be built on the basis of this truism. All other social institutions, especially the political system institutions, demand the existence of peace in order to be able to really exist and act, and accordingly, the existence of the military is actually a necessary precondition for any, not only optimal political functioning.

Without the military, therefore, there is no acceptable peace, and without such peace there is no predictability, control, normality and all that is provided by norms and law enforcement - "the existence of law... is a precondition for normal social life" [11]. Laws that regulate the society, and which are not 
the result of free decision of people and which people do not agree to, are imposed occupation laws that can exist only in unacceptable and slavish peace, and "do not have the same degree of obligation" ${ }^{21}$. Some authors even believe that peace is worthless if it is regulated by imposed laws - "laws, which are an essential component of peace, have to be accepted and enforced (both!), otherwise peace has no value" [12]. Therefore, although some other institutions are in charge of drafting and enforcing laws, which enable normal life in the society, the armed forces give meaning and enable the implementation of our laws, and therefore normal life. In the narrative about the redundancy of the military, there is a frequent argument that war is unlikely and that it can no longer happen. Even if we accept this claim extremely naively, it is not really an argument against the existence of the military, but the strongest confirmation of its value and fulfillment of its purpose (peace), and not through a means of war but through a means of deterrence. It is guarantor of peace, that is, absence of war; the military capable of eternally preserving peace is the best possible military.

\section{CONCLUSION}

The importance of concepts and the precise analysis of their meaning and correlations may not seem so great and essential out of philosophical discourse, but it definitely is. The lack of understanding the meaning of concepts and the implications of their use can often have serious consequences for individuals and the society as a whole. In the case of the armed forces, the lack of understanding the difference between the concepts of purpose and means is one of the factors influencing the perception of the significance and importance of the military in peace. The inadequate perception of the importance of the military has an impact on the attitude of the rest of political system towards the military institution, and also on the status and reputation of its members in the society. The clarification of this conceptual confusion is an important step towards achieving the optimal position of the armed forces in political system, which guarantees adequate evaluation of its members by the rest of the society in peacetime.

The state rests on enforcing law and ensuring normal and acceptable functioning for its citizens, which is the function of all institutions in political system. The precondition of each "normality" and legality is a state of peace, which is the purpose of the existence of the armed forces. Without peace that the armed forces provide to the society by means of war and deterrence, all other institutions of political system, as well as the state itself, would not be able to function sustainably, at least not for a longer period. Therefore, the state has the primary duty to maintain the optimal military in a state of peace $^{22}$, because giving up such an aspiration would mean giving up maintaining and defending peace, i.e. "giving up the right to authorize law enforcement" [11]. This state duty has to be articulated in an adequate relation of political system to the armed forces. General public, on the other hand, has to be educated about the essential importance of the military as the foundation for the functioning of all other institutions of political system in peace that it enables. Finally, educating general public about the purpose of the military and the means it uses to fulfill this purpose in the future contributes to the adequate evaluation of members of the armed forces and their social status, as they enable "normality" of life and functioning of all other important social institutions.

\section{Acknowledgment}

The paper was written as a result of the work on the scientific project of the Military Academyof the Defence University ,The military in the political system of Serbia”, which is financed by theMinistry of Defence of the Republic of Serbia (project number VA-DH /1/19-21).

\section{Endnotes}

'More about the processes that imply postmodern understanding of the world in: Ilija Kajtez and Dragan Stanar, ,Postmodern Thought and Modern World”, Creating Sustainable Community, Proceedings, Univerzitet Union Nikola Tesla, 2021, pp. 333346. [13] 
${ }^{2}$ Such orchestrated pressure through new media is often deliberately constructed and represents a form of subversive action and an increasingly popular tool in the arsenal of the socalled ,,hybrid” war.

3By political community we do not imply its primary meaning, but the entire ,,professional” political scene, i.e. a community of people engaged in political affairs and participating in the political decision-making process, at all levels within political system.

${ }^{4}$ It is impossible to ignore the influence of subversive activities of interested forces and the socalled stakeholders in creating the status and perception of the main social values and institutions, whose weakening is in their direct interest. Moreover, deep ideological blindness can very often lead to such processes, in which „the restructuring” of the world is recognized according to an ideologically acceptable and desirable pattern, whose values such as cosmopolitanism, social atomism, extreme liberalism, etc., may be incompatible with the existence of any firm and traditional social institutions.

In the broadest possible sense, it is perhaps only possible to view these concepts as two interfering concepts, although this is also questionable. More on the relations between the concepts in: Gajo Petrović, Logika, Zavod za udžbenike, Beograd, 2011, pp. 29-33. [14]

"It is interesting that the Ministry of Defence of Great Britain today was originally called the „War Office”, until 1964. It is similar with the United States Department of Defense today, which was previously called the „Department of War" and the „War Cabinet”.

"The Serbian Armed Forces are defined as an institution that „,defends the country from external armed threats”, state bodies „responsible” for the armed forces are called ministries or departments of defence, while in many countries (Finland, Australia, Israel, Ireland, etc.) instead of the syntagm ,,armed forces” the syntagm „,defence forces” is used. Even in the entire security system of a country, according to some authors, the military is classified in a subsystem called the ,national defence system”, which is different from the „national security” subsystem. More in: Zoran Dragišić, „Sistem nacionalne bezbednosti pokušaji definisanja pojma", Vojno delo, 3/2009, p. 165. [15]

${ }^{8}$ In addition to defence, all modern armed forces have additional missions, such as support to civil institutions and participation in international peacekeeping missions. However, the primary and main function of every military is always to defend a country from an armed attack.

${ }^{9}$ The interests and values of a state can be defended in other ways - through diplomacy, economy, culture, etc. - but none of that primarily falls within the scope of what the armed forces of a state are intended for.

${ }^{10}$ There is a significant difference between preventive and pre-emptive strike, especially considered from the perspective of moral and legal justification. The difference between the state of prevention and pre-emption, among other things, is constituted by factors such as the certainty of an attack, the proximity of a threat and the expected consequences of not taking strike action. When the „point of sufficient threat” is reached, i.e. when strike becomes reflexive, ,like raising one's hands in defence at the last moment", one can speak of pre-emptive strike. Majkl Volzer, Pravedni i nepravedni ratovi, Službeni glasnik, Beograd, 2010, pp. 113-114. [16]

'This perception is (un)intentionally strengthened by neoliberal attitudes that the process of globalization guarantees peace, that democratic countries do not wage war against each other, that national armies should be replaced by a supranational global armed force, etc.

${ }^{12}$ The reactions of the lay public, and also some media and civil society organizations, to the purchase of new material and technical resources for the military, to the increase in the salaries of the armed forces members, to the construction of apartments for military personnel, etc., unequivocally point to this phenomenon, because, according to a rule, the public is served a calculation that a great number of hospitals, kindergartens, parks, etc. could have been built/renovated with these funds. The recent public discussion on the justification for the reintroduction of conscription has again provoked an avalanche of reactions that funds for this activity would be spent in vain and pointlessly, and that it would be politically responsible and morally correct to redirect those funds to something that is ,,useful” for the society.

${ }^{13}$,"The dialectic of war and peace requires that the main premise of any definition of peace is the absence of war, while war is logically defined as the state in which peace is interrupted, i.e. does not exist.” Dragan Stanar, ,Teorija pravednog mira: implikacije i opasnosti normativne teorije pravednog mira", Politička revija, Vol. 68, 2/2021, p. 89. [17]

${ }^{14}$ The authors even believe that the armed forces are directly responsible for peace building during war, since the possibility of peace largely depends on the manner of warfare. More in: Dragan Stanar, Pravedan rat - između apologije i obuzdavanja rata, Dobrotoljublje, Beograd, 2019, pp. 201-296. [7] Ilija Kajtez, Srdjan Starčević, Bojana Ružičić, "The Essence of Phenomenon of Peace and the Notion of Peace Building", Vojno delo, 8/2018, pp. 5-23. [18]

${ }^{5}$ It should be noted that the armies take part in wars whose beginning they have not decided on, over whose duration they have no control and whose end they also do not decide on. The responsibility for war is in the sphere of politics, not in the sphere of the military. The very phenomenon of war is, in fact, completely meaningless if viewed outside the political context. As Starčević and Blagojević point out, „,war has its own grammar, but it does not have its logic, because its logic is always in the sphere of the political”. Srđan Starčević i Srđan Blagojević, „Kreveldov spor sa Klauzevicem - Da li je smisao rata politički? “, Srpska politička misao, Vol. 56, 2/2017, pp. 119-120. [19] 
${ }^{16}$ This is one of the things that distinguishes the armed forces from other actors in war, such as paramilitary formations and private military companies, which cannot always be claimed to have the end of war as soon as possible as its goal, nor the least possible casualties. More in: Dragan Stanar, "Paramilitary Organizations and Private Military Companies in War: How to Restrain What You Do Not Control?”, In Patrick Mileham (ed.), Jus Post Bellum - Restraint, Stabilisation and Peace, Brill Nijhoff, Leiden/Boston, 2020, pp. 362-387. [20]

${ }^{17}$ In recent decades, there has been a clear tendency to try to transform conflict into something that is very dangerous for freedom at global level by eliminating the possibility of war and its a priori criminalization. More on the implications of revisionism in the theory of just war in: Dragan Stanar, "Revisionism and New Conflicts: Negation of the Possibility of War", Srpska politička misao, Vol. 63, 1/2019, pp. 227-239. [21]

${ }^{18}$ Peace can mean a state in which drastic discrimination, exploitation, deprivation of dignity of a greater number of people are normalized, in which terror of institutions, slavery, violence, etc. are legalized. Therefore, the initial premise of pacifist reasoning, that every peace is better than any war, is obviously unfounded, as shown by the millennia of human history in which war was chosen as a more favourable solution than the existing conditions of peace.

${ }^{19}$ Rare states that do not have their own armed forces rely on the armed forces of other states or military alliances that guarantee them the preservation of peace. There is no „spontaneous” peace anywhere on the planet, created ex nihilo, not established and protected by someone. More about understanding the role of the armed forces in the society through history: Ilija Kajtez, Mudrost i mač, Medija centar „Odbrana”, Beograd, 2012. [22]

${ }^{20}$ As the popular saying goes, „Those who are reluctant to feed their own army shall feed a foreign army”. Some, or rather, someone's army always protects peace, even when the society decides that it will not be its military. In such situations, the question arises: is such peace desirable and good for those who live in it?

${ }^{21}$ More about the validity and legitimacy of law as an expression of free will of political collectivity in: Dragan Stanar, Etika međunarodne politike, Dobrotoljublje, 2021, pp. 170-179. [2]

${ }^{22}$ Maintaining the optimal military in a state of peace implies its professional development and adequate armament, which paradoxically can increase security challenges, if one enters the so-called ,arms race”. More in: Dragan Stanar, „Zatvorenikova dilema i paradoks trke u naoružanju", in: Sanja Mrazovac Kurilić, Ljiljana Nikolić Bujanović i Miša Stojadinović (eds.) Savremeni ekološki, društveni, politički i ekonomski izazovi, Univerzitet Union Nikola Tesla, Beograd, 2020, pp. 288-300. [23]

\section{REFERENCES}

1. Babić J. The Structure of Peace. Filozofski godišnjak. 2008;21:189-198. [Google Scholar]

2. Babić J. Ispravno i nužno - ogled o odbrani. Filozofski godišnjak. 2011(24):130-146. [SCIndeks] [PDF] [Google Scholar]

3. Babić J. Moral i naše vreme. Beograd: Službeni glasnik. 2005. [Google Scholar]

4. Hantington SP. Vojnik i država. Beograd: Centar za studije Jugoistočne Evrope + Fakultet političkih nauka + Diplomatska akademija. 2004. [Google Scholar]

5. Kajtez I, Stanar D. Postmodern Thought and Modern World. In: Creating Sustainable Community, Proceedings. Beograd: Univerzitet Union Nikola Tesla. 2021; p. 333-346. [Google Scholar]

6. Kajtez I, Starčević S, Ružičić B. The essence of phenomenon of peace and the notion of peace building. Vojno delo. 2018;70(8):5-23. [SCIndeks] [PDF] [Google Scholar]

7. Pavlović Z, Stanar D. Ubistvo u ratu - mržnja bez zločina i zločin bez mržnje. Human Rights Protection. 2019(1):75-88. [Google Scholar]

8. Petrović G. Logika. Beograd: Zavod za udžbenike. 2011. [Google Scholar]

9. Rodin D. War and Self-Defense. Oxford: Clarendon Press. 2004. [Google Scholar]

10. Stanar D. Paramilitary Organizations and Private Military Companies in War: How to Restrain What You Do Not Control? In: Mileham Patrick, editor(s). Jus Post Bellum: Restraint, Stabilisation and Peace. Leiden/Boston: Brill Nijhoff. 2020; p. 362-387. [Crossref] [Google Scholar]

11. Stanar D. Revisionism and New Conflicts: Negation of The Possibility of War. Srpska politička misao. 2019;63(1):227-239. [Crossref] [Google Scholar]

12. Stanar D. Zatvorenikova dilema i paradoks trke u naoružanju. In: Mrazovac-Kurilić Sanja;NikolićBujanovićLjiljana;StojadinovićMiša, editor(s). Savremeni ekološki, društveni, politički i ekonomski izazovi. Beograd: Univerzitet Union Nikola Tesla. 2020; p. 288-300. [Google Scholar]

13. Hew S. Preemption and Prevention in Historical Perspective. In: Shue Henry;RodinDavid, editor(s). Preemption: Military Action and Moral Justification. Oxford: Oxford University Press. 2007. [Google Scholar] 
14. Volzer M. Pravedni i nepravedni ratovi - moralni argument sa istorijskim primerima. Beograd: Službeni glasnik. 2010. [Google Scholar]

15. Vojska Srbije. O vojsci [Internet]. 2021 [cited 27.7.2021.]. Available from: http://www.vs.rs/sr_lat/jedinice/vojskasrbije.

16. Danilović N, Gordić M, Blagojević S. Savremeni sistemi bezbednosti. Beograd: Zavod za udžbenike. 2015. [Google Scholar]

17. Dragišić Z. Sistem nacionalne bezbednosti - pokušaj definisanja pojma. Vojno delo. 2009;61(3):162-176. [SCIndeks] [PDF] [Google Scholar]

18. Kajtez I. Mudrost i mač. Beograd: Medija centar 'Odbrana'. 2012. [Google Scholar]

19. Nikolić M, ur. Rečnik srpskog jezika. Novi Sad: Matica srpska. 2011. [Google Scholar]

20. Stanar D. Teorija pravednog mira: implikacije i opasnosti normativne teorije pravednog mira. Politička revija. 2021;68(2):87-103. [Google Scholar]

21. Stanar D. Etika međunarodne politike. Beograd: Dobrotoljublje. 2021. [Google Scholar]

22. Stanar D. Pravedan rat - između apologije i obuzdavanja rata. Beograd: Dobrotoljublje. 2019. [Google Scholar]

23. Starčević S, Blagojević S. Kreveldov spor sa Klauzevicem - da li je smisao rata politički? Srpska politička misao. 2017;56(2):117-134. [Google Scholar]

\section{Mir kao svrha vojske}

\section{Sažetak:}

Odnos političkog sistema, a u širem smislu i političke zajednice, prema vojsci u velikoj je meri definisan shvatanjem uloge i svrhe koju vojska ima u jednom društvu. Nerazumevanje istinske svrhe vojske često dovodi do neadekvatnog vrednovanja ove institucije, kako u političkom sistemu, tako i od strane šire javnosti. Cilj rada jeste definisanje mira kao svrhe vojske, koje će omogućiti ispravno shvatanje njene vitalne političke uloge kao nužnog okvira i preduslova postojanja i funkcionisanja svih ostalih institucija u društvu. $U$ radu se analizira percepcija uloge institucije vojske i njenih pripadnika i nudi alternativna definicija njene funkcije i svrhe, koja olakšava ispravan uvid u ulogu vojske u društvu i oslikava njena suštinska priroda. Intuitivno poimanje uloge vojske, kroz pogrešno interpretiranje instrumenta (rata) kao same svrhe, redukuje i njenu svrhu na rat, a time i determiniše odnos laičke političke javnosti prema ovoj instituciji i njenim pripadnicima. Zato je neophodno ponuditi adekvatan odgovor na pitanje: zašto je svrha vojske zapravo mir a ne rat, kakav je to mir, i kojim funkcijama ova institucija ispunjava svoju ulogu. Zaključuje se da ovako definisanu svrhu "dobrog" mira vojska realizuje dvostruko - u miru njegovim očuvanjem kroz funkciju odvraćanja, a u ratu njegovim što bržim uspostavljanjem kroz pobedu.

Ključne reči: vojska; mir; rat; svrha; sredstvo; zakoni 